УДК 94 (477.83/.86): 61 “1918/1919”

\title{
ОХОРОНА ЗДОРОВ'Я В ЗАХІДНО-УКРАЇНСЬКІЙ НАРОДНІЙ РЕСПУБЛІЦІ: ІСТОРИКО-АНТРОПОЛОГІЧНІ АСПЕКТИ
}

\author{
Лев ДАВИБІДА \\ Івано-Франківський обласний осередок \\ Всеукраїнської кампанії "Пам'ять Нації” \\ e-mail: lev.davybida@gmail.com \\ DOI: 10.15330/gal.32.83-91 \\ ORCID: 0000-0003-4794-2954
}

\begin{abstract}
Автор розглядає прочес становлення і функціонування системи охорони здоров'я ЗУНР, застосовуючи методологічні підходи, притаманні для історії повсякденного життя як історико-антропологічної дисиипліни. Особлива увага приділяється висвітленню організаційних заходів, спрямованих на розбудову ланок управління галуззю охорони здоров'я $і$ забезпечення циивільного населення медичною опікою, аналізується практична діяльність влади і окремих представників лікарської професії у иих процесах. На підставі вивчення архівних джерел, згромаджених у фонді 3982 "Державний секретаріат внутрішніх справ Західно-Украӥнської Народної Республіки. Відділ санітарний” Центрального державного архіву вищих органів влади та управління України (ЦДАВО України), охарактеризовано рівень доступності якісної медичної допомоги для пересічного мешкания Східної Галичини в 1918-1919 рр. в умовах занепаду санітарно-гігієнічних відносин, спричиненого тривалими військовими діями, а також з'ясовано, які практичні заходи проводилися задля покращення санітарного стану ЗУНР $і$ подолання інфекиійних захворювань.

Ключові слова: Західно-Украӥнська Народна Республіка, охорона здоров'я, лікар, шпиталь,
\end{abstract} аптека, реквізицїі.

Особливість історичної науки полягає у тому, що висновкам, отриманим у результаті досліджень, завжди можна знайти застосування у сьогоденні. Зокрема, переваги і недоліки у розбудові охорони здоров'я Західно-Української Народної Республіки цілком можуть враховуватися в подальшому реформуванні медичної галузі в Україні. Актуальності проблемі додає також й той факт, що як ЗУНР, так і сучасна Україна були втягнуті у перманентні військові дії, а отже, мали справу з великою кількістю хворих і поранених. В останні роки дедалі більше дослідників стали цікавитися згаданою проблемою. Насамперед, варто відзначити науковий доробок О. Сапіги ${ }^{1}$ та В. Рутара ${ }^{2}$, присвячений питанням медичного забезпечення і повсякденної гігієни бійців Української Галицької армії. Досить чітко висвітлено особливості державного регулювання медицини періоду ЗУНР у працях О. Сороки ${ }^{3}$ і К. Холейко ${ }^{4}$. Організаційні

\footnotetext{
${ }^{1}$ Сапіга О. П. Кадрове забезпечення медичної та санітарної служби УГА в 1918-1920 рр. Військовонауковий вісник. Академія сухопутних військ. Львів, 2011. Вип. 14. С. 93-107 ; Сапіга О. П. Організація військових госпіталів Української Галицької Армії та їх матеріальне забезпечення (1918-1920рр.). Наукові записки Тернопільського начіонального педагогічного університету імені Володимира Гнатюка. Серія : Історія. Тернопіль, 2010. Вип. 2. С. 79-85 ; Сапіга О. Початки формування медичної та санітарної служби Української Галицької Армії. Україна : культурна спадщина, наиіональна свідомість, державність. Львів, 2009. Вип. 18. С. 450-456.

2 Рутар В. Діяльність керівництва ЗУНР по організації закордонних поставок військового майна для Галицької армії. Гуманітарний журнал. 2011. № 3-4. С. 216-225 ; Рутар В. Повсякденна гігієна, методи лікування і профілактики захворювань військовиків Галицької армії (листопад 1918 - листопад 1919 рр.). Наукові зошити історичного факультету Львівського університету. 2015. Вип. 16. С. 175-187.

${ }^{3}$ Сорока О. Державне регулювання медичної діяльності на Прикарпатті у першій половині XX століття. Державне управління. 2012. № 18. С. 104-110.

${ }^{4}$ Холейко К. Особливості державного регулювання охорони здоров'я, санітарного і епідемічного стану в 1919-1921 роках. Українська Центральна Рада - світоч національного державотворення: історико-
} 
заходи української влади задля боротьби з інфекційними захворюваннями, поширеними в 1918 1919 рр., досліджував свого часу й автор даної статті. Однак крізь призму історико-антропологічного підходу процес становлення і функціонування охорони здоров'я ЗУНР розглянутим ще не був, тож це і визначило мету нашого дослідження.

Першочерговим завданням охорони здоров'я є організація та забезпечення доступного медичного обслуговування населення. Тобто вона передбачає, що будь-яка середньостатистична особа може і має право в разі потреби легко отримати як першу медичну допомогу, так i повноцінне клінічне обстеження та лікування. Однак для пересічного мешканця Східної Галичини в 1918-1919 pр. реалізація цього права була доволі проблематичною, попри всі зусилля влади, яка намагалася створити самостійну українську систему охорони здоров'я протягом невеликого терміну. Основною перешкодою для її побудови був українсько-польський військовий конфлікт, який одразу ж вніс свої корективи.

Структура уряду ЗУНР на момент його заснування 9 листопада 1918 р. передбачала існування окремого Державного секретаріату суспільного здоров'я на чолі з I. Куровцем ${ }^{5}$. Це пояснюється тим, що формування української медичної служби відбувалося за зразком колишньої австрійської санітарної системи, де існувало відповідне міністерство. Окремого “портфеля" вимагало і вкрай незадовільне санітарно-епідемічне становище Галичини, помножене на повоєнну економічну й господарську розруху. Але під час вимушеного відступу українського війська та уряду зі м. Львова 22 листопада 1918 р. І. Куровець не встиг евакуюватися і потрапив у полон, де пробув до лютого 1919 р. В умовах відсутності міністра, а також з міркувань ощадності та спрощення адміністративно-бюрократичного апарату управління, якого вимагав військовий стан, у новому уряді від 4 січня 1919 р. Державний секретаріат суспільного здоров'я був ліквідований. Натомість було утворено Санітарний відділ при Державному секретаріаті внутрішніх справ, очолений І. Куровцем після повернення з полону ${ }^{6}$.

Безпосередньо у повітах, як місцевих адміністративних центрах української влади, організація медичного забезпечення покладалася на повітових комісарів 7 . Їхні повноваження і обов'язки, окреслені 1 грудня 1918 р. в окремому “Обіжнику Ради державних секретарів до державних повітових комісарів про їх обов’язки та права”, передбачали, що “для збереження народного здоровля державні комісари повітові доложать всяких зусиль, щоби в кожнім повіті було відповідне число лікарів. Про стан здоровля в повіті треба прекладати Державному секретаріатові місячні звіти" повітового лікаря, який був головним медичним і санітарним урядником на місцевості. До обов'язків повітового лікаря входив контроль за діяльністю лікарень у місті та на території повіту, місцевого медичного персоналу, ведення контролю за епідемічним станом, дотриманням санітарних і гігієнічних норм у громадських місцях, вишкіл громадських санітарних контролерів, підбиття статистики захворювань і надсилання щомісячного звіту до центральних органів влади ${ }^{9}$. Для допомоги повітовим лікарям створювалися санітарні комісії ${ }^{10}$. У повітових санітарних комісіях працювали місцеві лікарі, аптекарі, ветеринари, уповноважені від громади.

правові уроки та сучасні реалії : матеріали круглого столу, м. Тернопіль, 10-11 берез. 2017 р. Тернопіль, 2017. С. 296-300.

${ }^{5}$ Тищик Б. Й., Вівчаренко О. А. Західноукраїнська народна республіка. 1918-1923 рр. (До 75-річчя утворення і діяльності). Коломия, 1993. С. 24.

${ }^{6}$ Павлишин О. Іван Куровець. Західно-Українська Народна Республіка. 1918-1923. Уряди. Постаті / за ред. Я. Ісаєвича. Львів, 2009. С. 139-140.

Сорока О. Державне регулювання медичної діяльності на Прикарпатті у першій половині XX століття. C. 107.

${ }^{8}$ Гай-Нижник П. П. Налагодження державної служби в добу Української революції. Державна служба України в історичному контексті: проблеми становлення та розвитку : зб. текстів виступів на наук.практ. конф. (м. Київ, 18 листоп. 2008 р.). Київ, 2009. С. 79.

9 Центральний державний архів вищих органів влади та управління України (ЦДАВО України). Ф. 3982. Оп. 1. Спр. 13. Арк. 1.

${ }^{10}$ Холейко К. Особливості державного регулювання охорони здоров'я, санітарного і епідемічного стану в 1919-1921 роках. С. 299. 
Завданнями комісій були пропаганда гігієни серед населення і допомога у виконанні санітарних наказів. Діяльність повітових лікарів і комісій контролювали санітарні інспектори 3. Левицький, М. Долинський, В. Янович, О. Грабовський ${ }^{11}$.

При розбудові цивільної медичної адміністрації уряду ЗУНР і місцевим представникам української влади довелося стикнутися з чималими труднощами, пов'язаними із браком кваліфікованих медичних працівників. Ще у довоєнний час на теренах Галичини проживало всього 63 практикуючих лікарів української національності ${ }^{12}$. Цього було замало, щоб охопити всі посади цивільної адміністрації, а ще треба було комусь служити у війську. Наприкінці листопада 1918 р. у газеті “Діло” було опубліковано наказ для всіх українських медиків у віці до п'ятдесяти років зголоситися до Державного секретаріату військових справ ${ }^{13}$. Переважна більшість обізнаних у медичній справі українців працездатного віку знаходилася на військовій службі.

В умовах війни питання мобілізації медиків не підлягало жодним сумнівам, але вона спричинилася до погіршення медичного забезпечення цивільних. Типовою стала ситуація, коли головним лікарем у двох повітах одночасно працювала одна і та ж особа. Зокрема В. Кобринський працював лікарем одразу в Коломийському і Печеніжинському повітах ${ }^{14}$. На початку 1919 р. місто Делятин з околицею залишилися без лікарського нагляду, оскільки місцевий лікар, поляк М. Богданський, не був практикуючим з огляду на вік і стан здоров'я. Тому коломийський повітовий комісар I. Стрийський підтримав прохання міського комісара Р. Галянковського до Окружної команди УГА в м. Коломиї про звільнення в запас міського лікаря А. Гарасовського, що відбував службу в тутешній запасній лічниці ${ }^{15}$. Домовитися з військовою владою вдавалося не завжди. Прохання Секретаріату внутрішніх справ про звільнення Д. Сприса 3 с. Озірної (сьогодні входить до складу м. Перемишляни Львівської обл.), який проходив військову службу в м. Кам’янці Струмиловій, на березень-квітень 1919 р. для боротьби $з$ висипним тифом, поширеним серед цивільного населення Перемишлянського повіту, було відхиленим. Причину відмови було вмотивовано тим, що в армії теж епідемія, а цілі відтинки фронту позбавлені лікарської допомоги ${ }^{16}$.

Кваліфікованих лікарів і молодшого медичного персоналу не вистачало по всій Галичині. Поповнювати штат доводилося за рахунок так званих “медиків" - студентів медичного факультету університету, що мали незакінчену вищу освіту. Як правило, вони працювали у військових госпіталях, санітарних колонах, помічниками хірургів і епідеміологами у найбільш заражених місцевостях ${ }^{17}$. Проблему медичних кадрів намагалося вирішити і відділення Українського Червоного Хреста в Галичині, утворене 27 лютого 1919 р. у м. Станиславові під керівництвом О. Прийми, яке організовувало курси санітарок і доглядальниць за хворими для українського жіноцтва ${ }^{18}$.

Українській владі доводилося залучати до адміністрування в галузі охорони здоров'я представників національних меншин - поляків, євреїв, німців. Їхній перехід на службу українській державі супроводжувався значними труднощами. Найскладніше цей процес протікав се-

\footnotetext{
${ }^{11}$ Щуровський В. Лікарі і медики у визвольній війні. 25-ліття Українського Лікарського Товариства $і$ Медичної громади. Чікаго, 1975. С. 106-129.

${ }^{12}$ Павлишин О. Соціально-політичний портрет українського проводу Галичини та Буковини в революції 1918-1919 років. Україна Модерна. Львів, 2000. Ч. 4-5. URL: http://chtyvo.org.ua/authors/Pavlyshyn_Oleh/ Sotsialno-politychnyi_portret_ukrainskoho_provodu_Halychyny_ta_Bukovyny_v_revoliutsii_1918-1919_rokiv/ (дата звернення: 10.09.2018).

13 До лікарів-Українців. Діло. 1918. 21 листоп. С. 4.

${ }^{14}$ ЦДАВО України. Ф. 3982. Оп. 1. Спр. 12. Арк. 25.

${ }^{15}$ ЦДАВО України. Ф. 3982. Оп. 1. Спр. 11. Арк. 43.

${ }_{17}^{16}$ ЦДАВО України. Ф. 3982. Оп. 1. Спр. 8. Арк. 3.

${ }^{17}$ Королько А., Давибіда Л. Санітарно-епідемічна ситуація на Покутті у роки національно-визвольних змагань західних українців 1918-1919 рр. Питання історії України. Збірник наукових праць кафедри історії України Чернівецького національного університету імені Юрія Федьковича. Чернівці, 2013. Т. 16. С. 63 ; Сапіга О. Початки формування медичної та санітарної служби Української Галицької Армії. C. $450-451$.

${ }_{18}$ Загальні збори товариства “Українського Червоного Хреста”. Нове життя. 1919. 9 берез. С. 2.
} 
ред поляків. Подекуди вони відповідно до закликів Польської ліквідаційної комісії бойкотували владу ЗУНР, або ж не поспішали приступати до виконання своїх обов'язків, займаючи вичікувальну позицію. Поширеним було явище, коли лікарі чи інші урядовці польського походження змінювали свої рішення: відмовлялися від служби під тиском місцевих польських організацій чи навпаки після першої відмови зважувалися ії продовжувати через матеріальні та інші обставини ${ }^{19}$.

Здебільшого лікарі-поляки все ж уникали державної служби, оскільки при вступі на неї потрібно було складати присягу новій владі, але погоджувалися на співпрацю як наймана робоча сила. Зокрема, в м. Перемишляни обов'язки повітового лікаря виконував поляк В. Сулковський, родом 3 Литви, за денну винагороду в сумі 30 крон. Місцевий повітовий комісар не вимагав від нього присяги, побоюючись, що В. Сулковський, попри хороше ставлення до українського режиму, відмовиться виконувати свої обов'язки в знак солідарності з польським суспільством, і повіт залишиться без лікаря ${ }^{20}$. На аналогічних умовах працював лікар Й. Батка ${ }^{21}$ у Скалатському повіті та К. Фліс у м. Рудках ${ }^{22}$. Наскільки добре виконували свої обов'язки такі працівники важко судити, бо відомості про їхню діяльність залишилися доволі уривчасті. Якщо згадуваний В. Сулковський цілком задовольняв місцеву владу, то лікар Я. Йоссе з Надвірнянського повіту, який після того, як покинув посаду повітового лікаря, за дорученням комісаріату певний час здійснював санітарний нагляд і складав звіти про поширення інфекційних хвороб, був запідозрений у недбайливому ставленні до обліку хворих на тиф і замовчуванні реальної їх кількості ${ }^{23}$.

Чимало представників національних меншин працювали у шпиталях, ставали міськими чи окружними лікарями (ці посади були контрактними), фізіологами та епідеміологами. Часом на роботу зголошувалися навіть іноземці. У березні 1919 р. І. Куровець повідомив Державний секретаріат внутрішніх справ про те, що до лікарської служби зголосився хірург 3 віденської клініки професора Айзельсберга Ф. фон Форстер за винагороду в 50 крон на день. Разом 3 доплатами, які він отримував за проведення операцій у військових шпиталях, місячна платня цього спеціаліста виносила 2 тис. крон в місяць ${ }^{24}$. 3-поміж інших світил віденської клініки вдалося запросити до праці у ЗУНР докторів Г. Гайріха, Р. Шпоннера та декількох інших ${ }^{25}$.

3 огляду на брак кваліфікованих спеціалістів Санітарний відділ та повітові комісаріати займалися пошуком кадрів за межами Галичини. Так, Золочівський комісаріат, де, станом на лютий 1919 р. ще не було повітового лікаря, уповноважив штабного медика Золочівської бригади, який відбував у відрядження до м. Києва, винайняти там когось на цю посаду при умові виплати 1-1,2 тис. карбованців заробітної плати в місяць. Контракт передбачалося укласти терміном на три місяці 3 можливістю його продовження ${ }^{26}$. На території Бродського повіту санітарною колоною, яка займалася дезінфекцією жител та одягу, керував фельдшер Кальченко 3 Катеринославської губернії ${ }^{27}$.

Часом поєднання цивільної і військової служби представниками нацменшин та іноземцями приносило шкоду республіці. Ключовим фактором виступало те, що вони розглядали свою працю не з точки зору користі для української справи, а суто як засіб збагачення. Я. Біненвальд, який працював у м. Бучачі міським та військовим лікарем при запасній сотні, уникав виконання службових обов'язків, натомість займаючись у робочий час приватною практикою. Більше того, навіть відверто зловживав своїм становищем міського фізика, оскільки змушував

\footnotetext{
${ }^{19}$ Томенчук Х. Організація місцевої виконавчої влади ЗУНР (жовтень 1918 - червень 1919 рр.) : історико-політологічний аналіз. Гілея. 2012. № 10. С. 556-562.

${ }^{20}$ ЦДАВО України. Ф. 3982. Оп. 1. Спр. 12. Арк. 15.

${ }^{21}$ Центральний держаний історичний архів України, м. Львів. Ф. 567. Оп. 1. Спр. 79. Арк. 15

${ }^{22}$ Там само. Арк. 35-36.

${ }^{23}$ ЦДАВО України. Ф. 3982. Оп. 1. Спр. 12. Арк. 16.

${ }^{24}$ Там само. Спр. 5. Арк. 7.

${ }^{25}$ Сапіга О. П. Кадрове забезпечення медичної та санітарної служби УГА в 1918-1920 рр... С. 95.

${ }^{26}$ ЦДАВО України. Ф. 3982. Оп. 1. Спр. 11. Арк. 8.

${ }^{27}$ Там само. Спр. 13. Арк. 31.
} 
місцевих проституток проходити медичний огляд не у приміщенні магістрату, як це передбачав закон, а в себе вдома, беручи плату за приватний візит. Були випадки завищення лікарської такси і відвертого вимагання хабарів: С. Коньський зі шпиталю в м. Долині вимагав за здійснення операції 2 тис. крон, а Я. Солтисік у Стрийському повіті відмовлявся від виїзду на провінцію, поки йому не сплатять за таку поїздку 800 крон $^{28}$. Аферу щодо проституток вчинив також виконуючий обов'язки повітового лікаря в Чорткові Р. Блявштейн, який примусово посилав лікуватися в госпіталі здорових жінок, якщо ті надто мало платили за візит.

За приблизними підрахунками місячний прибуток від подібних оборудок виносив близько 6-8 тис. крон ${ }^{29}$. Це різко відрізнялося від середньостатистичної лікарської платні в ЗУНР, що коливалася в межах 1-1,5 тис. крон в місяць для повітового, 600-900 - окружного лікаря чи медика, 1 тис. - для шпитального хірурга, 600 - для його помічника ${ }^{30}$. У цей же час місячна платня директора шпиталю виносила 350 крон, тому часто вона поєднувалася 3 приватною медичною діяльністю. Окружна акушерка мала ставку в розмірі 50 крон за місяць ${ }^{31}$. Додатково оплачувалися виїзди лікарів на територію повіту та відрядження, оскільки влада республіки не могла забезпечити службовим та санітарним транспортом усі повіти. Для відвідування населених пунктів у межах своєї юрисдикції лікарі користувалися приватним транспортом, винаймаючи підводи чи, де це було можливо, пересувалися залізницею. Затрачені на поїздку кошти поверталися з розрахунку 25 крон в день, якщо відстань не перевищувала 20 км від повітового міста. При перевищенні зазначеної відстані оплата зростала до 50 крон в день ${ }^{32}$.

Клінічна медична допомога у ЗУНР була погано розвинутою і неефективною через незадовільну матеріальну базу. У спадок від Австро-Угорської монархії республіці дісталася напівзруйнована війною мережа лікувальних закладів. Станом на 1918 p., існувало всього 27 загальних шпиталів у 46 повітових містах Східної Галичини. Однак стан медичних закладів не відповідав санітарним вимогам. Чимало госпіталів були в напівзруйнованому стані і не могли приймати пацієнтів. Зокрема, шпиталь у м. Бродах стояв напівпорожнім, бо в ньому не функціонувало опалення у трьох великих палатах ${ }^{33}$. Практично всі лікувальні заклади потребували ремонту, їм не вистачало інструментів, ліків, білизни та харчів. Навіть збільшення оплати за лікування 35 до 8 крон денно у третьому класі та з 10-15 до 20-25 крон - у першому не змінило того факту, що більшість шпиталів залишалися дотаційними і не могли проіснувати без державних позик, як-от лікарня у м. Долині. Це було пов'язано з подорожчанням продуктів харчування та відсутністю в населення коштів для оплати лікування ${ }^{34}$.

Практично ввесь персонал цивільних шпиталів був польським, тож доволі частими ставали випадки відвертого і прихованого саботажу у медичних закладах. У звіті з санітарного відрядження А. Целевича йшлося про те, що у м. Стрий в місцевих шпиталях бракує білизни, бо чималу їі кількість було вкрадено чи приховано під час перевороту ${ }^{35}$. Також про розкрадання шпитального майна в м. Долині польськими медсестрами свідчила місцева медичка. А. Целевич стверджував, що лікарі, сестри і обслуга цивільних шпиталів являють собою “твердиню польського духу в українській республіці”. Як приклад, він згадував порушену справу проти стрийського лікаря А. Малачиньського за переховування польського сотника ${ }^{36}$. Слід зауважити, що звинувачення полковника-лікаря не були безпідставними. Зокрема, директор загального шпиталю в м. Станиславів і член Державної ради здоров'я Г. Добруцький виступив одним 3 організаторів повстання бойовиків Польської організації військової у травні 1919 р. ${ }^{37}$.

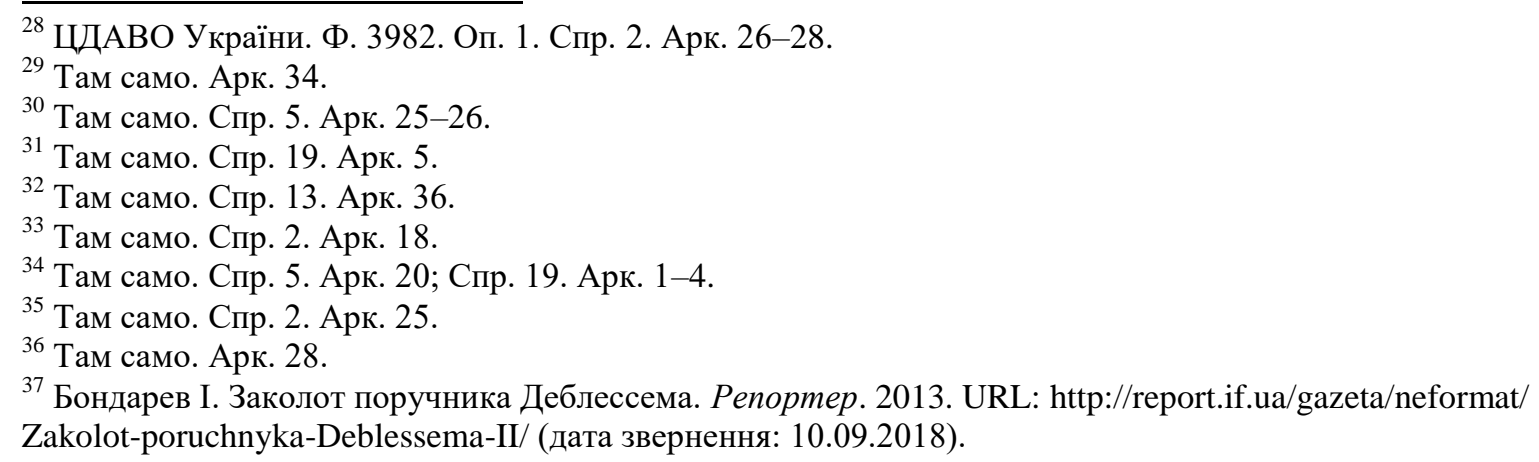


Недовіра до представників інших національностей, які працювали у сфері охорони здоров'я, спонукав керівників медичної служби ЗУНР шукати способи, якщо не повної їх заміни, то хоча б встановлення контролю за їхньою діяльністю з боку українських спеціалістів. I. Куровцем, А. Целевичем та А. Бурачинським пропагувався законопроект, згідно з яким до примусової державної служби у війську при боротьбі з інфекційними захворюваннями повинні були призиватися всі лікарі віком до 50 років без огляду на національність. По мірі набору лікарських сил військовозобов'язані українці мали би бути демобілізовані і влаштовані на цивільні посади місцевої адміністрації ${ }^{38}$. В умовах війни з Польщею цей проект заздалегідь був приречений на поразку, бо якість лікування українських вояків лікарем-поляком викликала чималі сумніви. Тож згаданий нормативний акт так і залишився на стадії розробки.

Геополітичні конфлікти зруйнували традиційні шляхи постачання ліків і дезінфекційних засобів у Галичину, тому постійно відчувався їхній брак. До того ж ведення воєнних дій і постійно зростаюча кількість поранених при недостатньому матеріальному забезпеченні, змушувала військових поповнювати свої запаси медикаментів через реквізиції в аптеках. Відомості про них доходили до Санітарного відділу Державного секретаріату внутрішніх справ з усіх куточків Галичини. У першу чергу вилученню підлягали спирт, перев'язочні матеріали та дезінфекційні засоби. Санітарний інспектор А. Целевич у своїй доповіді доносив, що реквізиції проводяться в неприпустимий спосіб, по кілька разів у всіх аптеках ${ }^{39}$. До Державного секретаріату внутрішніх справ також неодноразово надходили скарги аптекарів з Коломиї, Тернополя та інших міст на дії військових, внаслідок яких цивільні мешканці цілком втрачали можливість придбати хоча б якісь ліки. Тому влада була змушена 30 березня 1919 р. видати тимчасову заборону на примусове вилучення медичних засобів у аптеках, яка поширювалася на всю територію ЗОУНР. Доволі часто свої послуги республіці пропонували дрібні торговці, готові за відповідну плату привозити необхідні для аптек і шпиталів ліки з-за кордону ${ }^{40}$. Однак поповнення аптекарських запасів залишалося довготривалою i, в умовах небувалої інфляції, дорогою справою й ускладнювало і без того обмежений доступ збіднілого населення Галичини до медичної допомоги.

У лютому 1919 р. $з$ метою закупівлі медикаментів, дезінфекційних засобів та вербування санітарного персоналу вирушив до Австрії граф М. Тун-Гогенштайн, який добровільно зголосився до служби при Українському Червоному Хресті. Щоправда, особливою довірою Санітарного відділу та особисто I. Куровця згаданий делегат не користувався, оскільки мав славу авантюриста. Ці підозри справдилися, коли у травні 1919 р. з м. Відня до м. Станиславова надійшли перші чотири вагони гуманітарної допомоги, виділених Червоним Хрестом за посередництва графа М. Туна-Гогенштайна. Коли вагони було відчинено, то виявилося, що чимало одягу, шкіри і ниток зіпсовано, а медикаментів та дезінфекційних засобів взагалі не було. Лікарському персоналу, що прибув 3 м. Відня для боротьби з епідемією висипного тифу за посередництва графа, бракувало відповідної кваліфікації. У переважній більшості це були шахраї, які не мали жодного відношення до медицини ${ }^{41}$.

Якщо в Українській Галицькій армії командири вимагали від своїх підлеглих дотримання елементарних правил чистоти, то особиста гігієна і санітарна свідомість пересічного цивільного мешканця Галичини бажала б кращого ${ }^{42}$. Попри всі застереження і заборони, пов'язані із загрозливим поширенням інфекційних хвороб, насамперед висипного тифу, селяни нехтували власною безпекою і відвідували масові зібрання, провідували хворих, приходили на похорони. Це змусило владу вдатися до запровадження штрафних санкцій за порушення санітарних приписів. Розміри штрафу сягали від 100 до 5 тис. крон. За відсутності коштів міг також накладатися арешт терміном на 5-20 ді ${ }^{43}$. Міста, 3 огляду на брак дезінфекційних за-

\footnotetext{
${ }^{38}$ ЦДАВО України. Ф. 3982. Оп. 1. Спр. 2. Арк. 33.

${ }^{39}$ Там само. Спр. 5. Арк. 8.

${ }^{40}$ Там само. Спр. 8. Арк. 8 ; Рутар В. Діяльність керівництва ЗУНР по організації закордонних поставок військового майна для Галицької армії... С. 222.

${ }^{41}$ ЦДАВО України. Ф. 3982. Оп. 1. Спр. 17. Арк. 13.

${ }^{42}$ Рутар В. Повсякденна гігієна, методи лікування і профілактики захворювань військовиків Галицької армії (листопад 1918 - листопад 1919 рр.)... С. 178.

${ }^{43}$ ЦДАВО України. Ф. 3982. Оп. 1. Спр. 1. Арк. 4.
} 
собів та робочої сили, теж перебували в жахливому санітарному стані. У м. Станиславові, де у січні-травні 1919 р. перебував уряд ЗУНР, абсолютно нехтувалися санітарні приписи: "Санаційні відносини у сих місцевостях $є$ страшне, по вулицях повно болота, по подвір'ях лежать нечистоти, виходки занечищені, калові ями переповнені, кирниці зле почищені... Управа міста безсильна, бо не вистачає коней, возів, фірманів і людей для згортання болота і вивозу нечистот, також попсовані дороги"44.

Місця масового скупчення людей - вокзали, крамниці, ярмаркові площі, ресторації та готелі, - відверто слугували розплідниками інфекційних хвороб через неохайність, а то й цілковиту відсутність, вбиралень, плювальниць і рукомийників. Інспекція у складі лікарів А. Бурачинського та А. Целевича розкритикувала міські залізничні станції в Тернополі, Бродах, Бібрці, Ходорові, Долині, Кам'янці Струмиловій і в Сколім, де нечистоти лежали просто на пероні і заносилися до вагонів 3 підошвами взуття ${ }^{45}$. Інспектори також помічали у вагонах $\mathrm{i}$ готелях вошей, що свідчило про відсутність дезінфекції в цих закладах і у транспорті ${ }^{46}$. Подібна гігієнічна неосвіченість, соціально-економічні та культурно-побутові проблеми призводили до епідемій інфекційних хвороб: грипу “іспанки”, червінки, туберкульозу, кашлюку, скарлатини, дифтерії, черевного та висипного тифу, трахоми тощо. Надзвичайного поширення набула короста, яка охопила навіть інтелігентні верстви населення ЗУНР.

Втрата м. Львова в листопаді 1918 р. створила для Санітарного відділу Державного секретаріату внутрішніх справ ще одну проблему. Справа в тому, що єдина на території Галичини лікарня для психічнохворих знаходилася у Кульпаркові, тому після окупації цієї місцевості поляками уряд ЗУНР втратив можливість лікувати там своїх громадян. Тим часом воєнне лихоліття та пошесті ставали також і причиною психічних розладів у багатьох галичан. Зокрема, у с. Магдалівка Скалатського повіту вся родина померла від висипного тифу, залишилася тільки одна жінка, яка втратила розум і вважалася небезпечною для жителів села ${ }^{47}$. Тому божевільних утримували в непристосованих приміщеннях під наглядом охорони і лікарською опікою. Уряд ЗУНР намагався закласти шпиталь для лікування таких пацієнтів у с. Язлівець біля м. Бучача, але цей план так і залишився нереалізованим ${ }^{48}$.

Санітарний відділ ЗУНР, повітові комісаріати та лікарі займалися також просвітницькою діяльністю, несучи гігієнічні знання в широкі маси. Тому видавалися різноманітні відозви, інструкції та перестороги, в яких розповідалося про те, як слід вести себе при проявах ознак висипного тифу, про способи передачі збудників хвороб, засоби дезінфекції та особистої гігієни ${ }^{49}$. Дбали і про фізичне та гігієнічне виховання дітей. 3 ініціативи Державного секретаріату освіти і віросповідань 27-29 квітня 1919 р. відбулися збори, де обговорювалися питання реорганізації шкільництва. На збори було запрошено членів УЛТ І. Куровця та Я. Грушкевича, які поділилися ще довоєнними планами запровадження в українських школах курсу гігієни та взяли участь в обговоренні відповідної шкільної програми ${ }^{50}$. Однак несприятлива політична кон'юнктура та відступ українських військ за р. Збруч у липні 1919 р. завадили втіленню цієї програми в життя так само, як і поклали край іншим починанням ЗУНР у справі побудови державної системи управління охороною здоров'я краю.

Отже, попри зусилля влади ЗУНР створити систему охорони здоров'я, яка б охопила все населення Східної Галичини якісною медичною допомогою, ій це не вдалося. Головною причиною цієї невдачі став українсько-польський військовий конфлікт, що вилився у нестачу кваліфікованих медичних кадрів українського походження для забезпечення військових і цивільних потреб, труднощі 3 матеріально-технічною базою та перешкоди у поповненні санітарних запасів за кордоном. Неабияк шкодила справі також неосвіченість і необізнаність пересічних галичан у питаннях гігієни та правил дотримання чистоти, традиційна недовіра до пред-

\footnotetext{
${ }^{44}$ Там само. Спр. 5. Арк. 5.

45 Давибіда Л. Боротьба з інфекційними захворюваннями в Західно-Українській Народній Республіці. Галичина. Науковий і культурно-просвітній краєзнавчий часопис. Івано-Франківськ, 2014. Ч. 25-26. С. 183.

${ }^{46}$ Там само. Арк. 6 ; ЦДАВО України. Ф. 3982. Оп. 1. Спр. 7. Арк. 1.

${ }^{47}$ ЦДАВО України. Ф. 3982. Оп. 1. Спр. 11. Арк. 19.

${ }^{48}$ Щуровський В. Лікарі і медики у визвольній війні... С. 110.

${ }^{49}$ ЦДАВО України. Ф. 3982. Оп. 1. Спр. 1. Арк. 3-6.

${ }^{50}$ Там само. Спр. 11. Арк. 4-5.
} 
ставників лікарської професії. Що ж стосується питання діяльності медико-санітарних організацій національних меншин ЗУНР, то воно наразі ще дуже слабко відображене в історіографії, тож потребує більш ретельного збору джерел і детального дослідження.

\title{
HEALTHCARE IN THE WEST UKRAINIAN PEOPLE'S REPUBLIC: HISTORICAL ANTHROPOLOGY ASPECTS
}

\author{
Lev DAVYBIDA \\ Ivano-Frankoivsk regional branch of All-Ukrainian campaign "Memory of the Nation" \\ e-mail:lev.davybida@gmail.com
}

Summary

The article deals with the process of formation and functioning the health care system of the West Ukrainian People's Republic. The author applies the methodological approaches which are inherent in the history of everyday life as a historical and anthropological discipline. Particular attention is paid to the description of organizational measures aimed at building parts of the management of the health sector and providing the civilian population with medical care. The practical activity of the authorities and individual representatives of the medical profession in these processes is analysed. The level of availability of quality medical care for the average inhabitant of Eastern Galicia in 1918-1919 is characterized on the basis of the study of archival sources collected in the fund 3982 "The State Secretariat of Internal Affairs of the Western Ukrainian People's Republic. The Department of Sanitary” of the Central State Archives of Supreme Bodies of Power and Government of Ukraine. Also, it is finding out what practical measures were taken to improve the sanitary state of the West Ukrainian People's Republic and overcome infectious diseases. The author concludes that, despite all the efforts of the ZUNR authorities, they did not succeed to create a healthcare system which would be sufficient for covering the entire population of Eastern Galicia by quality medical care. The main reason for this failure was the Ukrainian-Polish military conflict. It provoked a shortage of qualified medical personnel Ukrainian origin. It was forced to serve at the front and could not appease the needs of civilians. That's why the representatives of other nationalities were involved in the service on the position of district doctors. It was also associated with certain difficulties because the Poles mostly sabotaged service in favour of the Ukrainian state. The war has also caused material and technical problems in the healthcare sector, in particular, the lack of sanitary materials and medicines and the difficulties in importing them from abroad. The traditional ignorance in the hygiene of Galician people and the distrust for the representatives of the medical profession were also usual problems.

Keywords: West Ukrainian People's Republic, healthcare, doctor, hospital, pharmacy, requisition.

\section{REFERENCES}

Bondarev I. Zakolot poruchnyka Deblessema. Reporter. 2013. URL: http://report.if.ua/gazeta/neformat/ Zakolot-poruchnyka-Deblessema-II/ (data zvernennia: 10.09.2018). [in Ukrainian].

Hai-Nyzhnyk P. P. Nalahodzhennia derzhavnoi sluzhby v dobu Ukrainskoi revoliutsii. Derzhavna sluzhba Ukrainy $v$ istorychnomu konteksti : problemy stanovlennia ta rozvytku : zb. tekstiv vystupiv na nauk.prakt. konf. (m. Kyiv, 18 lystop. 2008 r.). Kyiv, 2009. S. 37-90. [in Ukrainian].

Davybida L. Borotba z infektsiinymy zakhvoriuvanniamy v Zakhidno-Ukrainskii Narodnii Respublitsi. Halychyna. Naukovyi i kulturno-prosvitnii kraieznavchyi chasopys. Ivano-Frankivsk, 2014. Ch. 25-26. S. $182-187$. [in Ukrainian].

Do likariv-Ukraintsiv. Dilo. 1918. 21 lystop. S. 4. [in Ukrainian]. Ukrainian].

Zahalni zbory tovarystva "Ukrainskoho Chervonoho Khresta". Nove zhyttia. 1919. 9 berez. S. 2. [in

Korolko A., Davybida L. Sanitarno-epidemichna sytuatsiia na Pokutti u roky natsionalno-vyzvolnykh zmahan zakhidnykh ukraintsiv 1918-1919 rr. Pytannia istorii Ukrainy. Zbirnyk naukovykh prats kafedry istorii Ukrainy Chernivetskoho natsionalnoho universytetu imeni Yuriia Fedkovycha. Chernivtsi, 2013. T. 16. S. 62-67. [in Ukrainian].

Pavlyshyn O. Ivan Kurovets. Zakhidno-Ukrainska Narodna Respublika. 1918-1923. Uriady. Postati / za red. Ya. Isaievycha. Lviv, 2009. S. 139-140. [in Ukrainian].

Pavlyshyn O. Sotsialno-politychnyi portret ukrainskoho provodu Halychyny ta Bukovyny v revoliutsii 1918-1919 rokiv. Ukraina Moderna. Lviv, 2000. Ch. 4-5. URL: http://chtyvo.org.ua/authors/Pavlyshyn Oleh/Sotsialno-politychnyi_portret_ukrainskoho_provodu_Halychyny_ta_Bukovyny_v_revoliutsii_1918-1919_ rokiv/ (data zvernennia: 10.09.2018). [in Ukrainian].

Rutar V. Diialnist kerivnytstva ZUNR po orhanizatsii zakordonnykh postavok viiskovoho maina dlia Halytskoi armii. Humanitarnyi zhurnal. 2011. № 3-4. S. 216-225. [in Ukrainian]. 
Rutar V. Povsiakdenna hihiiena, metody likuvannia i profilaktyky zakhvoriuvan viiskovykiv Halytskoi armii (lystopad 1918 - lystopad 1919 rr.). Naukovi zoshyty istorychnoho fakultetu Lvivskoho universytetu. 2015. Vyp. 16. S. 175-187. [in Ukrainian].

Sapiha O. P. Kadrove zabezpechennia medychnoi ta sanitarnoi sluzhby UHA v 1918-1920 rr. Viiskovonaukovyi visnyk. Akademiia sukhoputnykh viisk. Lviv, 2011. Vyp. 14. S. 93-107. [in Ukrainian].

Sapiha O. P. Orhanizatsiia viiskovykh hospitaliv Ukrainskoi Halytskoi Armii ta yikh materialne zabezpechennia (1918-1920 rr.). Naukovi zapysky Ternopilskoho natsionalnoho pedahohichnoho universytetu imeni Volodymyra Hnatiuka. Seriia: Istoriia. Ternopil, 2010. Vyp. 2. S. 79-85. [in Ukrainian].

Sapiha O. Pochatky formuvannia medychnoi ta sanitarnoi sluzhby Ukrainskoi Halytskoi Armii. Ukraina : kulturna spadshchyna, natsionalna svidomist, derzhavnist. Lviv, 2009. Vyp. 18. S. 450-456. [in Ukrainian].

Soroka O. Derzhavne rehuliuvannia medychnoi diialnosti na Prykarpatti u pershii polovyni XX stolittia. Derzhavne upravlinnia. 2012. № 18. S. 104-110. [in Ukrainian].

Tyshchyk B. Y., Vivcharenko O. A. Zakhidnoukrainska narodna respublika. 1918-1923 rr. (Do 75-richchia utvorennia i diialnosti). Kolomyia, 1993. 120 s. [in Ukrainian].

Tomenchuk Kh. Orhanizatsiia mistsevoi vykonavchoi vlady ZUNR (zhovten 1918 - cherven 1919 rr.) : istoryko-politolohichnyi analiz. Hileia. 2012. № 10. S. 556-562. [in Ukrainian]

Kholeiko K. Osoblyvosti derzhavnoho rehuliuvannia okhorony zdorovia, sanitarnoho i epidemichnoho stanu v 1919-1921 rokakh. Ukrainska Tsentralna Rada - svitoch natsionalnoho derzhavotvorennia : istorykopravovi uroky ta suchasni realii: materialy kruhloho stolu, m. Ternopil, 10-11 berez. 2017 r. Ternopil, 2017. S. 296-300. [in Ukrainian].

TsDAVO Ukrainy. F. 3982. Op. 1. Spr. 1. 21 ark. (Vytiahy z "Vistnyka derzhavnikh zakoniv" ta rozporiadzhennia Sanitarnoho viddilu Sekretariatu vnutrishnikh sprav pro borotbu z zaraznymy zakhvoriuvanniamy). [in Ukrainian].

TsDAVO Ukrainy. F. 3982. Op. 1. Spr. 2. 36 ark. (Zvedeni zvity po Zakhidno-Ukrainskii Narodnii Respublitsi pro sanitarnyi stan povitiv). [in Ukrainian].

TsDAVO Ukrainy. F. 3982. Op. 1. Spr. 5. 26 ark. (Lystuvannia z Sekretariatom vnutrishnikh sprav pro materialnu dopomohu hospitaliam, zakupku medykamentiv, zbilshennia likariv ta vzahali medychnoho personalu, pro ulashtuvannia zruchnykh pomeshkan dlia hospitaliv). [in Ukrainian].

TsDAVO Ukrainy. F. 3982. Op. 1. Spr. 7. 5 ark. (Lystuvannia z sekretariatamy shliakhiv ZakhidnoUkrainskoi Narodnoi Respubliky i dyrektsii zaliznyts Zakhidno-Ukrainskoi Narodnoi Respubliky ta podatkovym uriadom v Stanyslavovi pro borotbu z epidemiiamy cherevnoho ta sypnoho tyfiv). [in Ukrainian].

TsDAVO Ukrainy. F. 3982. Op. 1. Spr. 8. 19 ark. (Lystuvannia z Sekretariatom viiskovykh sprav Zakhidno-Ukrainskoi Narodnoi Respubliky pro rekvizytsiiu likiv, pro borotbu $\mathrm{z}$ antysanitarnym stanom $\mathrm{v}$ mistakh, pro nestachu likariv). [in Ukrainian].

TsDAVO Ukrainy. F. 3982. Op. 1. Spr. 11. 80 ark. (Lystuvannia z povitovymy komisariatamy v Bohorodchanakh, Berezhanakh, Zbarazhi, Zolochevi, Borshchevi, Brodakh, Bibrtsi. Dolyni, Deliatyni, Horodentsi, Drohobychi, Zhydachevi, Zhovkvi pro sanitarnyi stan povitiv, pro poshyrennia epidemii ta borotbu z nymy, pro zakupku medykamentiv, pro vlashtuvannia pomeshkan dlia hospitaliv). [in Ukrainian].

TsDAVO Ukrainy. F. 3982. Op. 1. Spr. 12. 28 ark. (Lystuvannia z povitovymy komisariatamy v Kolomyi, Kopychyntsiakh, Kalushi, Nadvirnii, Pidhaitsiakh, Pechenizhyni, Peremyshlianakh pro poshyrennia poshesnykh khvorob: cherevnoho, pliamystoho tyfiv, borotbu z nymy ta pro sanitarnyi stan povitiv, asyhnuvannia hroshei na borotbu $\mathrm{z}$ epidemiiamy ta zaraznymy khvorobamy ta pro pryznachennia likariv na robotu do hospitaliv).

TsDAVO Ukrainy. F. 3982. Op. 1. Spr. 13. 143 ark. (Lystuvannia z povitovymy komisariatamy v Radekhovi, Stryiu, Stanislavi, Sambori, Sokali, Skalati, Sniatyni pro sanitarnyi stan v povitakh, asyhnuvannia hroshei na borotbu z epidemiiamy ta zaraznymy khvorobamy ta pro pryznachennia likariv na robotu do hospitaliv). [in Ukrainian].

TsDAVO Ukrainy. F. 3982. Op. 1. Spr. 17. 13 ark. (Lystuvannia z okremym likariamy pro pryiom yikh na robotu ta borotbu $\mathrm{z}$ epidemiiamy, pro zakupku medykamentiv ta inshe). [in Ukrainian].

TsDAVO Ukrainy. F. 3982. Op. 1. Spr. 19. 15 ark. (Lystuvannia z viddilom derzhavnoi zhandarmerii v Stanyslavovi pro rekvizytsiiu pryvatnykh aptek). [in Ukrainian].

TsDIAL Ukrainy. F. 567. Op. 1. Spr. 79. 60 ark. (Zvity starostv ta povitovykh likariv pro medykosanitarnyi stan v povitakh pid chas polsko-ukrainskoi viiny (1918-1919). [in Ukrainian].

Shchurovskyi V. Likari i medyky u vyzvolnii viini. 25-littia Ukrainskoho Likarskoho Tovarystva $i$ Medychnoi hromady. Chikaho, 1975. S. 106-129. [in Ukrainian]. 